\begin{tabular}{|l|cc|c|}
\hline & Port-Said Engineering Research Journal \\
\hline
\end{tabular}

\title{
Effect of the Presence of Soft Clay on the Structural Design of Highway Sections
}

\author{
M. El Gendy ${ }^{1}$, A. Mohamady ${ }^{2}$, T. Nabil ${ }^{3}$ and M. Shams ${ }^{4}$.
}

\begin{abstract}
Construction over soft clay soils have always been a great challenge in the field of geotechnical engineering especially when designing infrastructure. Because of the low shear strength and high compressibility of this soil, many engineering problems such as slope instability, bearing capacity failure and excessive settlement could occur either during or after the construction phase. The design of highway pavements on soft clay soil still remains a very challenging issue, it can cause problems such as roadbed instability or excessive total and differential settlements. The main objective of this research is to study the effect of the presence of the soft clay on the structural design of pavement sections. Results of this study show that the investigated soft clay soil has lower CBR value $(0.509 \%)$ and modulus of compressibility $\left(\mathrm{E}_{\mathrm{s}}=129.8 \mathrm{kN} / \mathrm{m}^{2}\right)$, therefore it is not suitable for pavement construction. By using cyclic loading model device manufactured for this study, the settlement under pavement achieved 120.05, 120.32 and $12.28 \mathrm{~mm}$ for natural soft clay, using geotextile and using geotextile with geogrid together respectively.
\end{abstract}

Key words: Soft clay, Pavement, Geotextile, Geogrid, Cyclic loading.

\section{INTRODUCTION}

Permanent roads carry larger traffic volumes and typically have flexible (asphalt) or rigid (Portland cement concrete slabs) surfacing over a base layer of compacted aggregate. The combined surface and base layers act together to support and distribute traffic loading to the subgrade. A difficult problem in highway works exists when the sub-grade soil is soft clay. Stiff soils having high clay contents have the tendency to swell when their moisture content is allowed to increase [1]. On the other hand, soft soil foundation problems can be attributed to the following areas [2]: (1) Low subgrade bearing capacity and stability. (2) Settlement, horizontal displacement and differential settlement. (3) Embankment liquefaction under dynamic loads, instability and seismic subsidence can also take place in loose saturated sands. (4) Infiltration and sabotage may also cause other problems.

${ }^{I}$ Professor of Geotechnical Engineering and Foundations, Faculty of Engineering, Port Said University, Egypt.

${ }^{2}$ Associate Professor of Highway and Airport Engineering, Faculty of Engineering, Zagazig University, Egypt.

${ }^{3}$ Lecturer, Mechanical Engineering Department, Faculty of Engineering, Suez Canal University., Egypt.

${ }^{4}$ Corresponding author, Assistant Lecturer and Ph.D. Student, Civil Engineering Department, Faculty of Engineering, Suez Canal University,

Egypt

https://dx.doi.org/10.21608/pserj.2019.49559
The soil stabilization methods can be classified into [3]:

1- Mechanical Stabilization

2- Stabilization by using different types of ad mixers

- Lime Stabilization.

- Cement stabilization.

- Chemical stabilization

- Fly ash stabilization

- Rice husk ash stabilization

- Bituminous stabilization

- Thermal stabilization

- Electrical stabilization

- Stabilization by geo-textile and fabrics

- Recycled and waste products etc.

\section{Experimental Work}

\subsection{Tested Soft Clay Soil}

The soft clay soil samples are obtained from East Port Said, Egypt. Samples are placed in secure closed molds and then transported to the laboratory while preserving their consistency and natural water content. 


\subsubsection{Tested Soil Index Properties}

Index tests are conducted on the soft clay specimens. All the tests are performed according to the appropriate ASTM standards for the purpose of classification and quantification of their properties.

\subsubsection{Consolidation Test}

Consolidation Oedometer tests are carried out on specimens prepared from the collected soft clay. This test is performed to determine the magnitude and rate of volume decrease that a laterally confined soil specimen undergoes when subjected to different vertical pressures. Consolidation test is performed to study the compressibility of the soft clay soil used in this work.

\subsubsection{California Bearing Ratio (CBR) Test}

The California Bearing Ratio (CBR) test was developed by the California State highway department, and is one of the most common strength tests conducted to evaluate subgrade quality of soils and the suitability of soils for subbase and base courses in pavements. The test was outlined in ASTM D1883 [4] and AASHTO T193 [5].

\subsection{Manufacturing Small Scale Cyclic Loading Model Device}

\subsubsection{Testing Tank and Highway Model}

These experimental methods have been concerned with the load-settlement behavior of highway pavement on soft clay soils. Small scale model tests are performed to simulate the real improvement field conditions, but in a suitable scale for laboratory testing. The testing tank inside dimensions were $0.9 \times 0.9 \mathrm{~m}$ in plan and $0.4 \mathrm{~m}$ in depth.

The failure wedge beside the pavement strip is extended up to a distance of 2-2.5B ( $\mathrm{B}$ is the width of the road - one lane) on either side of the road. Also, the failure wedge is extended down to the depth of 1.1B below the road.

From these observations, it is clear that the tank width used in the current investigation is sufficiently large enough to prevent the effect of the tank boundaries on the results [6].

\subsubsection{Cyclic Loading Model}

This test method is used to study the effect of cyclic loading on highway sections due to weakness in the subgrade soil under the highway sections.
Cyclic loading device, as shown in Figure (1), is an electrically powered device capable of moving a steel wheel with a diameter of 8 inch $(20.36 \mathrm{~cm})$ and width of 1.85 inch $(4.7 \mathrm{~cm})$ over a test specimen. The maximum speed of the wheel must be approximately $1.1 \mathrm{ft} / \mathrm{sec}$. $(30.5 \mathrm{~cm} / \mathrm{sec})$. These data are simulating the concept of the WheelTracking Test device. This device is provided with a sensor and an arduino connected to a computer for measuring the surface deflection with time, and it can measure deflections at smaller time intervals as low as one second.

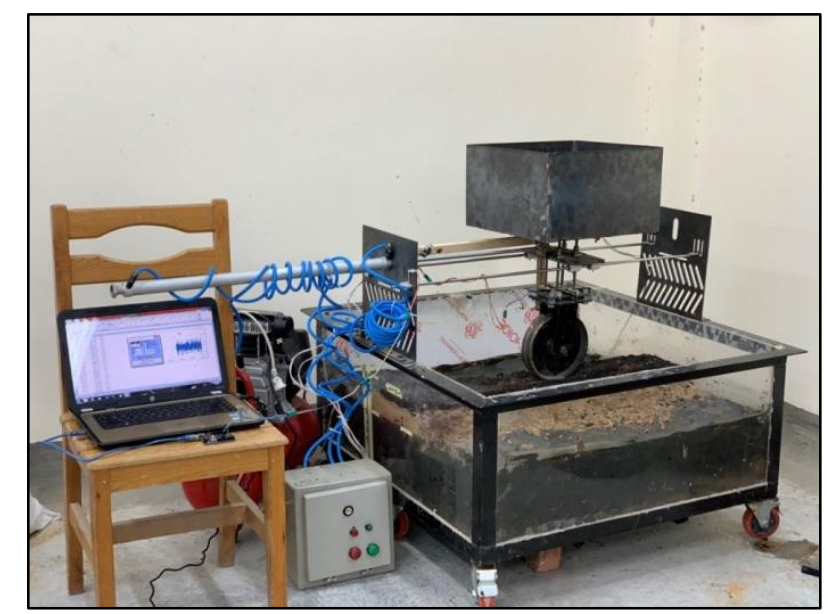

Figure (1): The Cyclic Loading Device during Operation.

In this study, the experiment duration was two hours long or till reaching failure. The deflection readings with time are recorded every one minute.

\subsection{Pavement Preparation}

\subsubsection{Soil Preparation as a Subgrade Layer}

Soft clay soil is poured into the tank to fill about $20 \mathrm{~cm}$ of the tank full height, which is $40 \mathrm{~cm}$. The soil test surface was then carefully leveled by pavement strip while causing no disturbance to the soft clay underneath, as shown in Figure (2). 


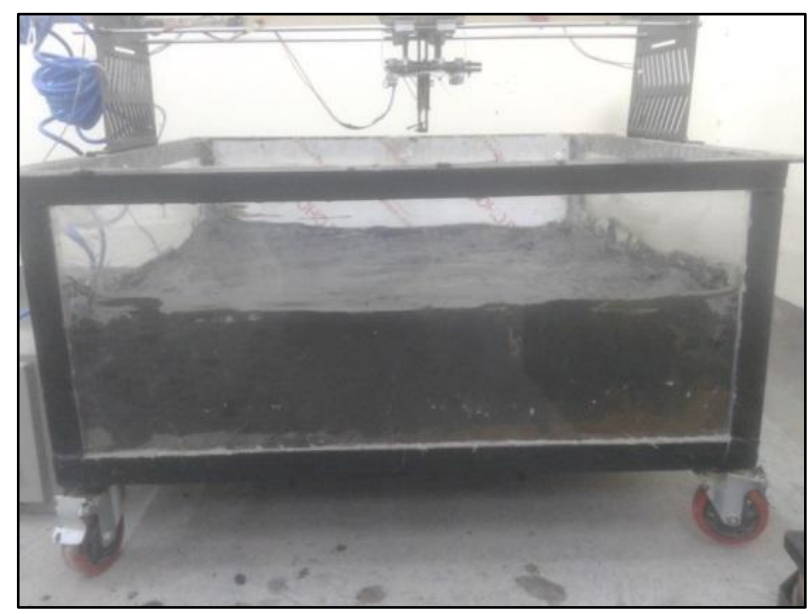

Figure (2): Soft Clay Soil Preparation as a Subgrade layer.

\subsubsection{Base Course Layer}

The base course is constructed directly above the subgrade layer, as shown in Figure (3). The material of the processed aggregate base is a mixture of course and fine aggregates. The material obtained from "Ataka" quarry, Suez Governorate, is prepared and mixed in $\mathrm{km}$ 17 mixer, Abo-Khalifa, Ismailia Governorate.

The maximum dry density of the base coarse soil, which is tested in the laboratory using the modified Proctor test, was $2.16 \mathrm{gm} / \mathrm{cm}^{3}$ and the corresponding optimum moisture content is $6.90 \%$, for compacted fill for the aggregate base coarse layer.

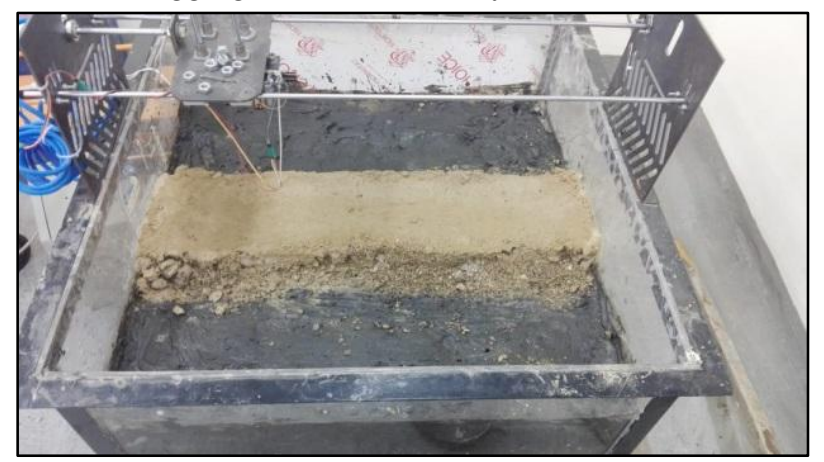

Figure (3): Base Course Layer Preparation.

\subsubsection{Asphalt Concrete Layer}

Asphalt concrete layer was directly placed on top of the base course, as shown in Figure (4).

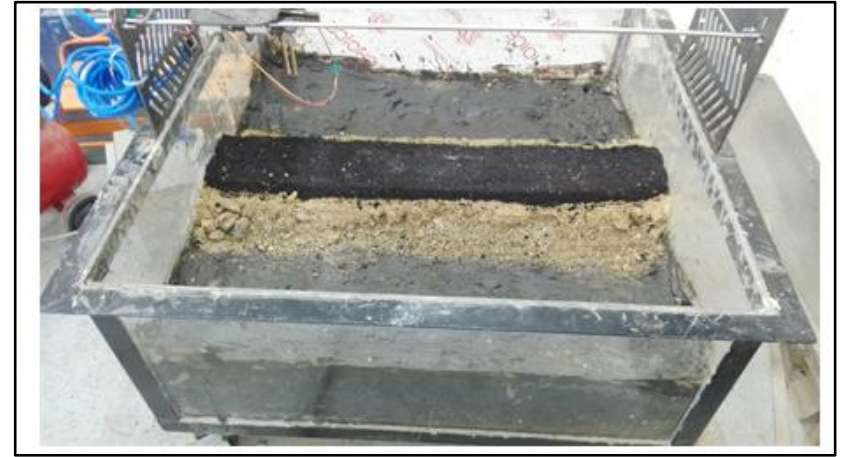

Figure (4): Asphalt Concrete Layer Preparation.

Asphalt concrete mixtures used in this study are shown in Figure (5), and composed of dolomite aggregate as coarse portion, crushed dolomite as fine portion and dolomite dust filler. These materials are mixed with asphalt cement (60-70) used as the bituminous material. The gradation of asphalt mix used in this study was 7A (Sandy Layers) as defined by the Egyptian Specifications.

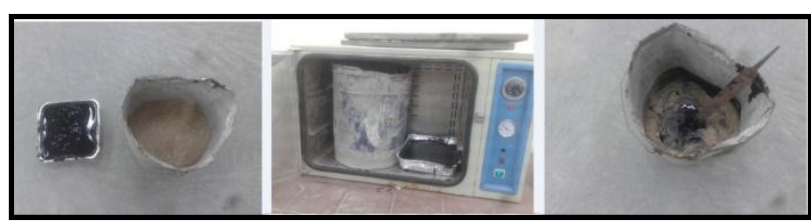

Figure (5): Asphalt Concrete Mixture Preparation.

\subsection{Pavement Model Tests}

This section presents tests conducted in the laboratory to simulate cyclic loading on the highway sections using the small scale cyclic loading model device, and to measure the surface deformations on the highway sections above the soft clay soil before and after soil treatment.

In this study, the thickness of the used asphalt layer was $2 \mathrm{~cm}$, the thickness of the base layer was 10 $\mathrm{cm}$ and the thickness of the soft clay layer was $20 \mathrm{~cm}$ at a scale of 1:6 when compared to the full-scale dimensions for simulation of flexible pavement in the tank.

\subsubsection{Reference Test (Without Improvement)}

The reference axle load weight selected was $80 \mathrm{kN}$ (18,000 pounds). The $80-\mathrm{kN}$ (18,000-pound) axle load was also the reference used by the AASHO road test in the early 1960 's. The passage of one $80-\mathrm{kN}$ (18,000-pound) axle load would result in the application of one EAL (or equivalent axle load). 
AASHTO 2012, suggests that the tire contact area of a wheel consisting of two tires is usually assumed to be a rectangle with dimensions of $50.8 \mathrm{~cm} \times 25.4 \mathrm{~cm}$ (width $\times$ length) and the area depends on the tire load [7].

By scale 1:6 the EAL weight will be $13.3 \mathrm{kN} \approx 1359 \mathrm{~kg}$ and since the contact area of the truck wheel is around $(50.8 \mathrm{~cm} \times 25.4 \mathrm{~cm})$ as defined by AASHTO, then the stresses by wheel will be $(1359 /(50.8 \times 25.4))=1.05 \mathrm{~kg} / \mathrm{cm}^{2}$. So, in this experiment the load applied by the wheel is $(1.05$ $x(4.5 \times 3.5))=16.5 \mathrm{~kg}$.

In this experiment, the soft clay soil is placed in the tank as a subgrade layer, followed by the sections of the road pavement; base and asphalt layers, without any improvement, as shown in Figure (6). That's why it's called a reference case.

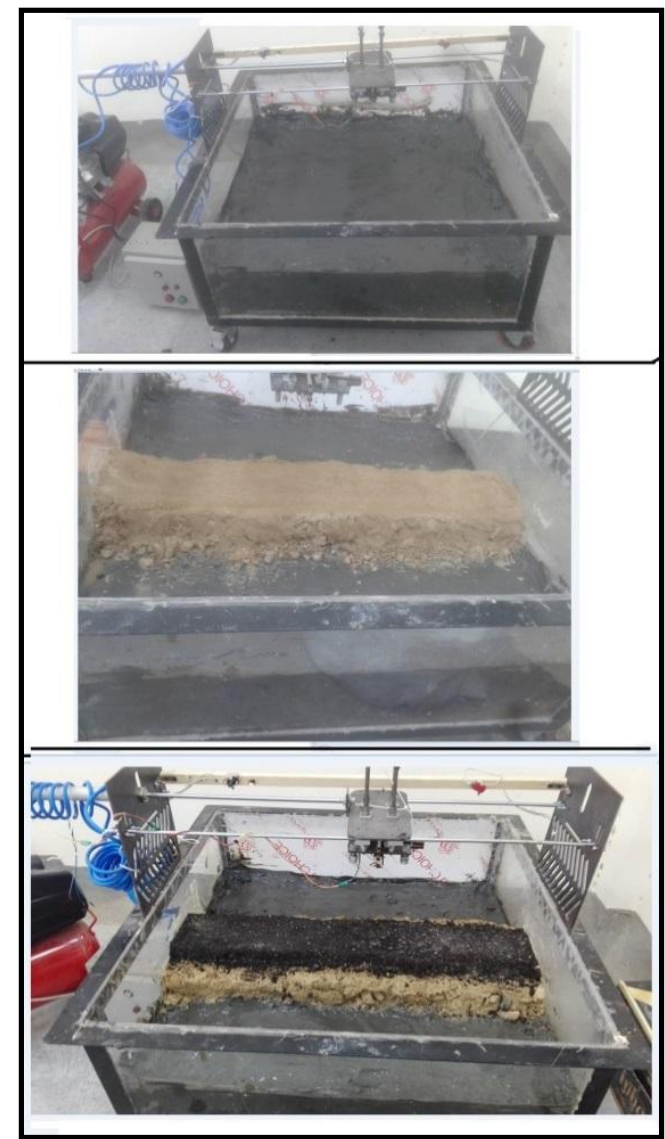

Figure (6): Reference Case Preparation.

\subsubsection{Improvement with Geotextile}

This experiment dealt with the geotextiles which was majorly used as reinforcement of weak soil. Geotextiles are flexible textile fabrics of controlled permeability, and are used to provide filtration, separation or reinforcement in soil, rock and waste material. Geotextile layer is placed between subgrade and base layer. Figure (7) shows the operating layer preparation to enhance the ability of the subgrade to sustain other pavement layers. Figure (8) shows the geotextile layer preparation and Figures (9) and (10) show the base and asphalt layer preparation respectively.

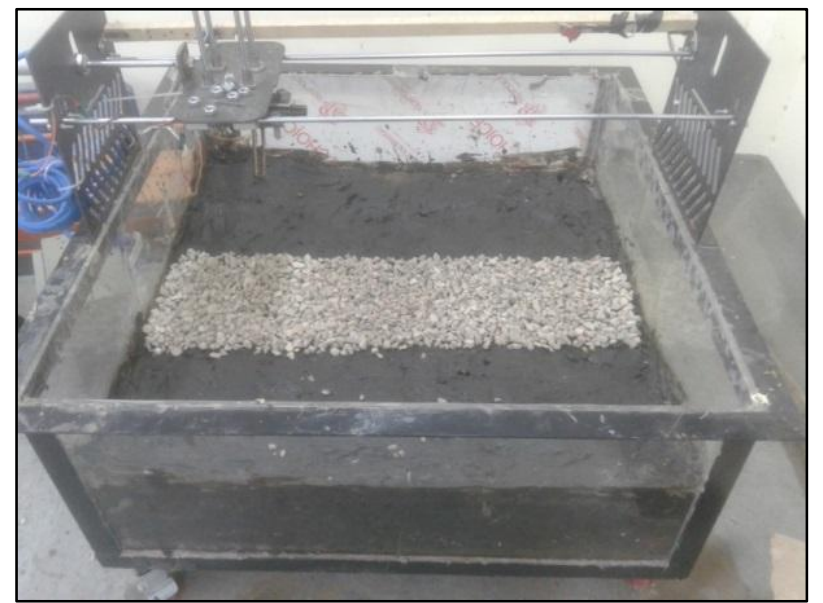

Figure (7): Operating Layer Preparation.

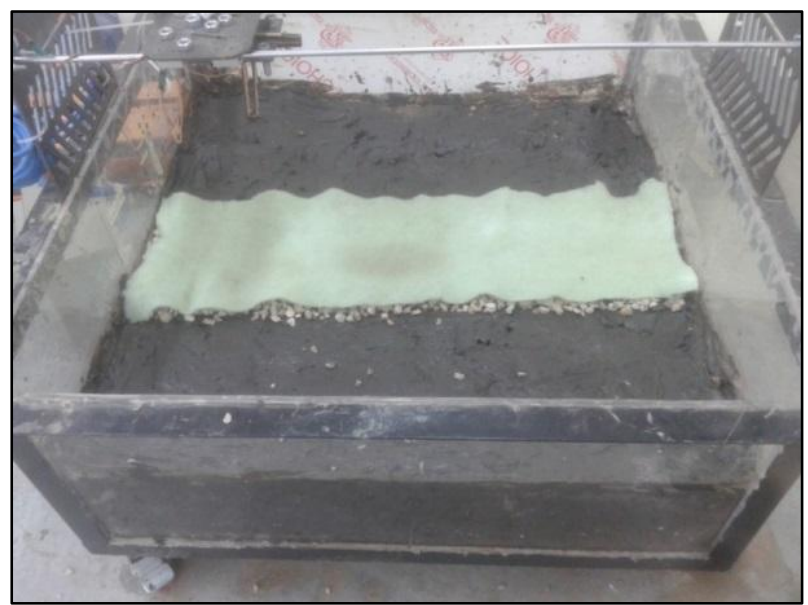

Figure (8): Geotextile Layer Preparation.

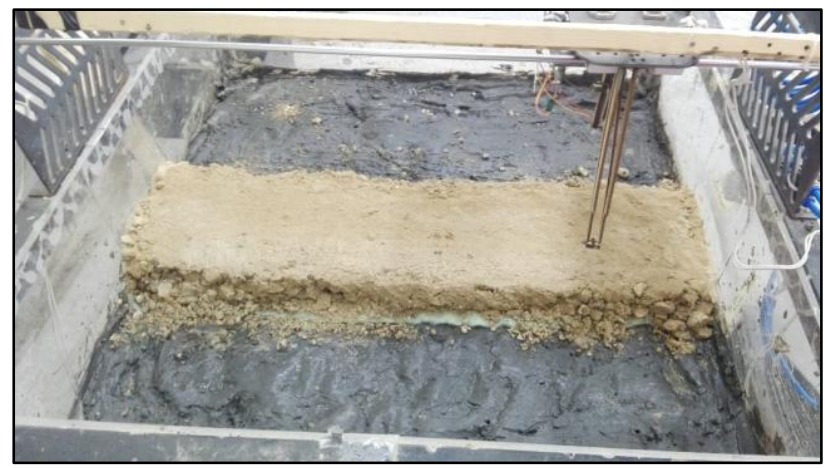

Figure (9): Base Layer Preparation. 


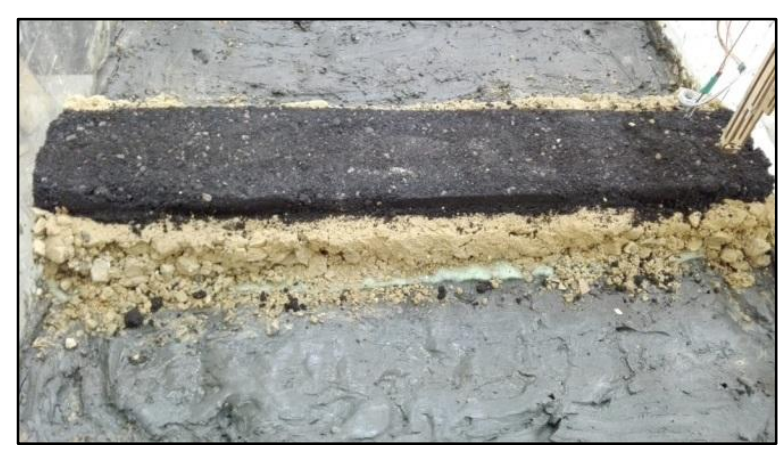

Figure (10): Asphalt Layer Preparation.

\subsubsection{Improvements with Geotextile and Geogrid}

Geogrid is a Stiff in one direction and flexible of the other, made of polymer grid like sheets with large aperture. Geogrids are used primarily as a reinforcement of soft soils and waste masses. Pavement preparation and soil improvement with geotextile and geogrid together are shown in Figure (11).

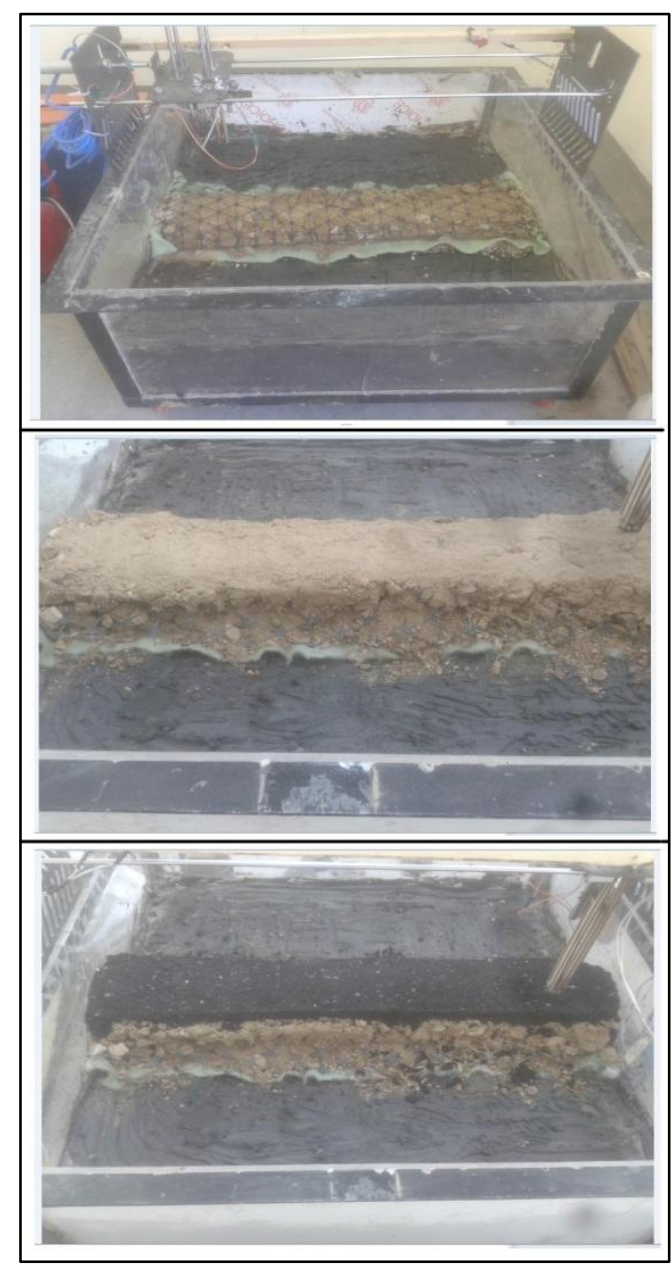

Figure (11): Improvement with Geotextile and Geogrid.

\subsection{Summary of the Investigated Modifying Scenarios}

The following Table (1) presents the investigated scenarios for stabilization of soft clay and improvement of the pavement section.

Table (1): Investigated Modifying Scenarios.

\begin{tabular}{|c|c|c|c|}
\hline $\begin{array}{c}\text { Modifying } \\
\text { Scenarios }\end{array}$ & $\begin{array}{c}\text { Natural Soft } \\
\text { Clay }\end{array}$ & Geotextile & Geogrid \\
\hline S1 & $\sqrt{ }$ & & \\
\hline S2 & $\sqrt{ }$ & $\sqrt{ }$ & \\
\hline S3 & $\sqrt{ }$ & $\sqrt{ }$ & $\sqrt{ }$ \\
\hline
\end{tabular}

\section{RESULTS AND DISCUSSION}

\subsection{Soil Index Properties}

Soil index tests are performed on soft clay according to ASTM standard procedures. Results of the index tests are presented in Table (2).

Table (2): Soil Index Test Results.

\begin{tabular}{|l|c|}
\hline Water Content (\%) & 49.60 \\
\hline Liquid Limit (\%) & 66.00 \\
\hline Plastic Limit (\%) & 37.60 \\
\hline Plasticity Index (\%) & 28.40 \\
\hline Specific Gravity & 2.70 \\
\hline USCS Classification & $\mathrm{MH}$ \\
\hline
\end{tabular}

\subsection{Soil Consolidation Test Results}

The specimen had a water content of $49.6 \%$ and was tested to a maximum stress of $355.28 \mathrm{kN} / \mathrm{m}^{2}$. Specific results of the consolidation test results are presented in Table (3).

Table (3): Consolidation Test Results.

\begin{tabular}{|l|c|}
\hline Water Content $(\mathrm{Wc})$ & $49.6 \%$ \\
\hline Compression index $(\mathrm{Cc})$ & 0.46 \\
\hline Swelling index $(\mathrm{Cs})$ & 0.115 \\
\hline $\begin{array}{l}\text { Coefficient of change in } \\
\text { volume (mv) }\end{array}$ & $7.7 \times 10^{-3}\left(\mathrm{~m}^{2} / \mathrm{kN}\right)$ \\
\hline $\begin{array}{l}\text { Modulus of Compressibility } \\
(\text { Es) }\end{array}$ & $129.84\left(\mathrm{kN} / \mathrm{m}^{2}\right)$ \\
\hline
\end{tabular}


The recorded measurements include settlements measured at different elapsed times under different loads. The relation between stress and void ratio in loading and unloading stages are presented in Figure (12).

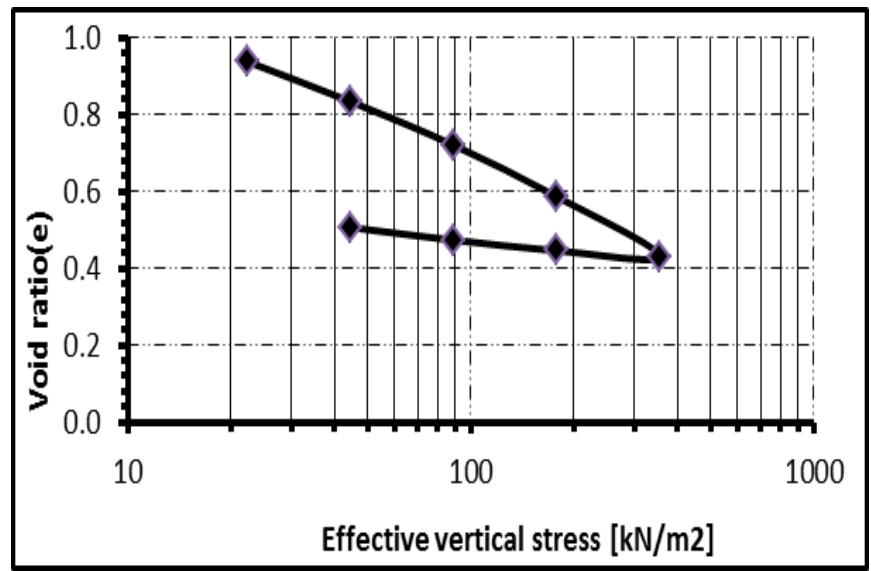

Figure (12): Consolidation Test Results for Natural Soft Clay.

\section{3}

\section{CBR at Original (Natural) Soft Clay Soil}

The CBR test was conducted on the natural soil sample without any stabilization material. Figure (13) shows CBR for original soil specimen.

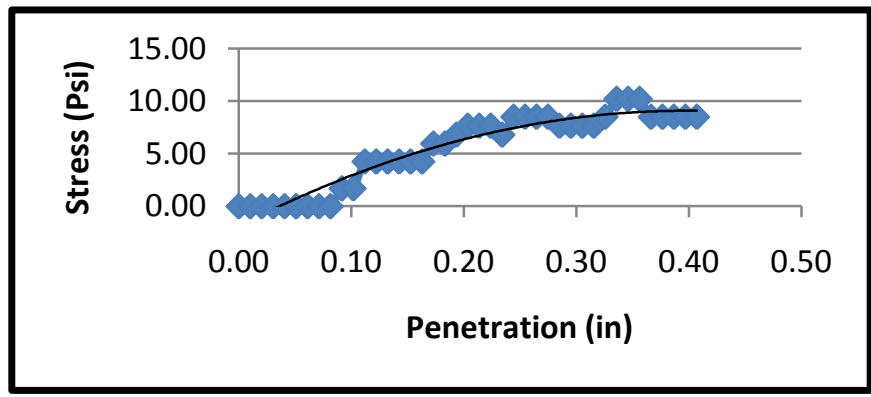

Figure (13): CBR for Original Soil Specimen.

The investigated soft clay soil has very low CBR value $=0.509 \%$, therefore it is not suitable for pavement construction.

\subsection{Pavement Model Tests Results for Natural Soft Clay}

The roadbed soil (subgrade soil) behavior depends on the settlement-time behavior of the repeated loading. The load applied by the wheel is $16.5 \mathrm{~kg}$. The following sections present results of applying cyclic loading on the natural soft clay soil and on improved soft clay soil using the investigated scenarios presented in Table (1).

\subsubsection{Reference Test (Without Improvement)}

Figure (14) presents the settlement and time curve for natural soft clay without improvement, scenario S1. Results show that, most of the settlement occurred in the first 12 minutes. After that the rate of settlement increase was decreased with time. The total failure of the pavement was achieved after 38 minutes of the test starting time; and the recorded settlement was 120.05 $\mathrm{mm}$. In this situation, the pavement section completely punched into the soft clay soil, as shown in Figure (15).

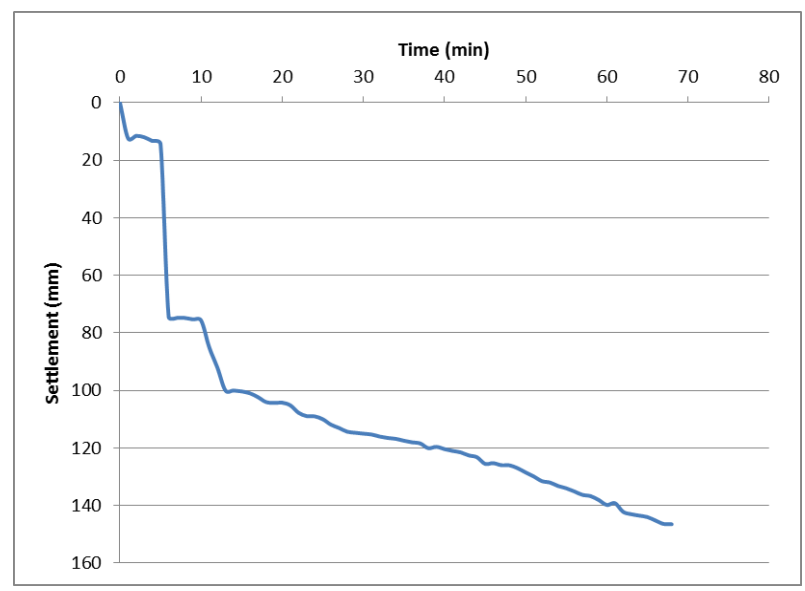

Figure (14): Settlement -Time Curve, S1.

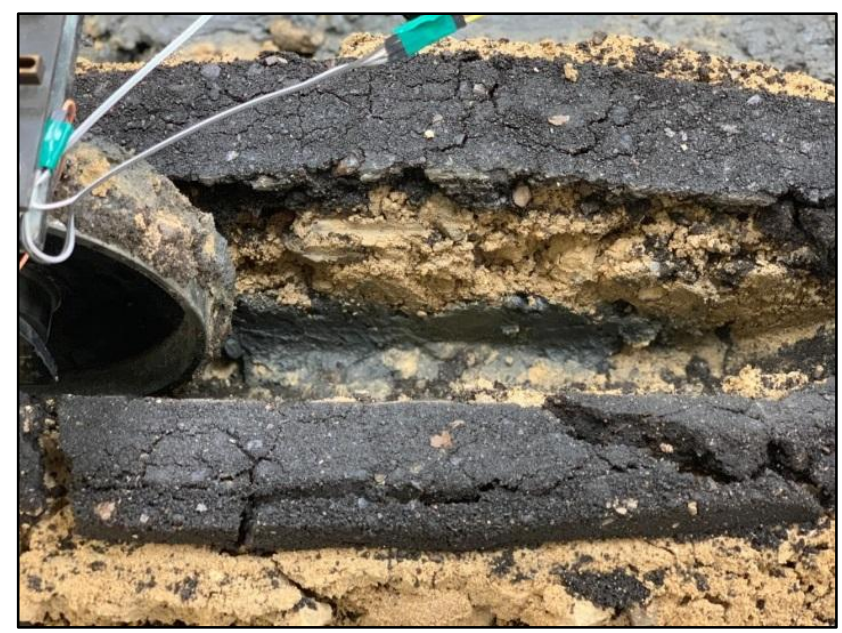

Figure (15): The Failure Shape, S1.

\subsubsection{Improvement with Geotextile}

Enhancing the soft clay using geotextile, scenario S2, was prepared and tested. Figure (16) shows the time-settlement curve for natural soft clay improved by geotextile (S2). It is noticed that the rate of settlement increase was increasing over time till reaching the soft clay layer after 48 minutes with a maximum settlement of $120.32 \mathrm{~mm}$, as shown in Figures (17). 


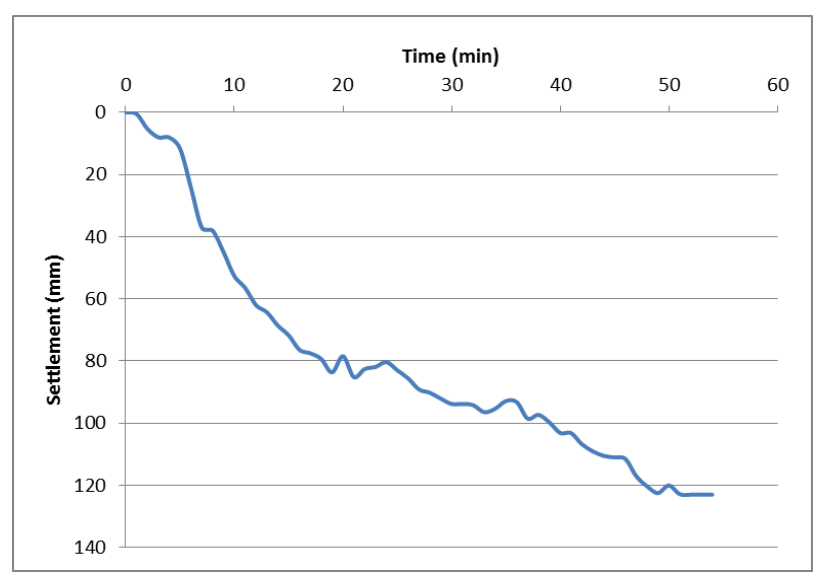

Figure (16): Settlement -Time Curve, S2.

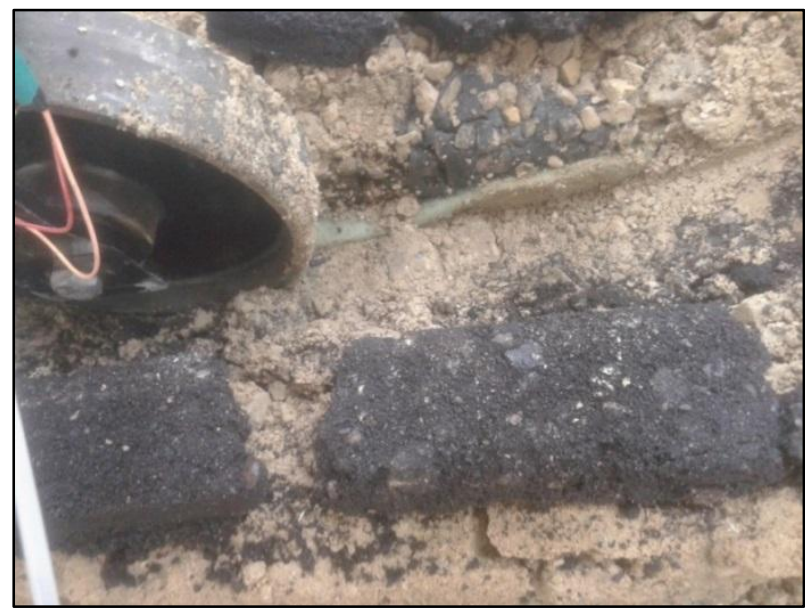

Figure (17): The Failure Shape, S2.

\subsubsection{Improvement with Geotextile and Geogrid}

Figure (18) shows the relationship between settlement and time for natural soft clay improved by geotextile and geogrid, scenario S3. It is noticed that the rate of settlement increase was increasing by lower rate than that in both scenarios $\mathrm{S} 1$ and $\mathrm{S} 2$ over time. The maximum measured settlement occurred after 120 minutes and was $12.28 \mathrm{~mm}$, as shown in Figure (19).

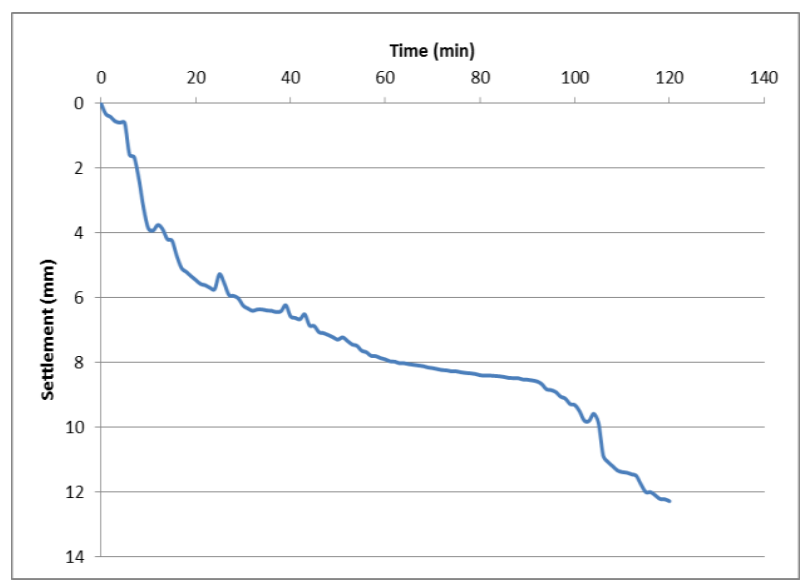

Figure (18): Settlement-Time Curve, S3.

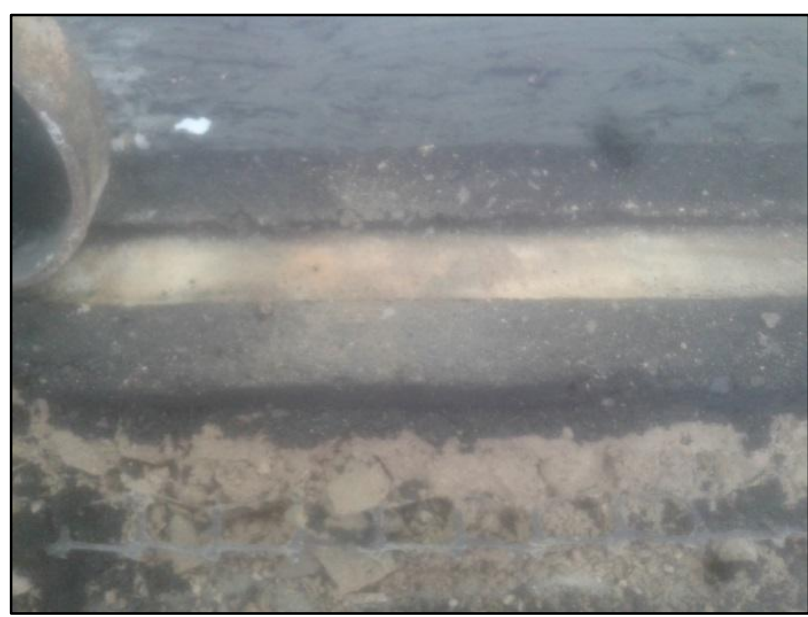

Figure (19): The Deflection Shape, S3.

\subsection{Summary of Time-Settlement Values for the Investigated Scenarios}

The following table summarizes the settlement with time values for each scenario as well as the percent settlement reached compared to the reference scenario $\mathrm{S} 1$.

Table (4): Time - Settlement Values for the Investigated Scenarios.

\begin{tabular}{|c|c|c|c|}
\hline Scenarios & $\begin{array}{c}\text { Time } \\
(\mathrm{min})\end{array}$ & $\begin{array}{c}\text { Settlement } \\
(\mathrm{mm})\end{array}$ & $\begin{array}{c}\% \\
\text { Settlement* }\end{array}$ \\
\hline S1 & 38 & 120.05 & $100 \%$ \\
\hline S2 & 48 & 120.32 & $100 \%$ \\
\hline S3 & 120 & 12.28 & $10.23 \%$ \\
\hline
\end{tabular}

* The percent obtained compared to the percent of scenario S1. 


\section{CONCLUSIONS}

1- The investigated soft clay soil has low CBR value of $(0.509 \%)$, and a modulus of compressibility of Es $=129.84 \mathrm{kN} / \mathrm{m}^{2}$, therefore it is not suitable for pavement construction and needs an improvement method.

2- The measured settlements were $120.05,120.32$ and $12.28 \mathrm{~mm}$ for natural soft clay, using geotextile and using geotextile with geogrid together, respectively.

3- The percent of settlement was $100 \%$ and $10.23 \%$ when using geotextile and geotextile with geogrid as compared by reference case (natural soft clay without improvement).

4- The use of geotextile only as an improvement has no significant effect.

5- The use of geogrid enhances greatly the pavement to sustain the traffic load by reducing significantly the total settlement over a much longer operation time.

\section{References}

[1] Chen, F. H. (1981): Foundations on Expansive Soils. Amsterdam: Elsevier Scientific Publishing Company.

[2] Lin, Y. and He, Y. (2011): Key Construction Technology for Highway on Soft Foundation. Advanced Materials Research. ISSN: 1662-8985, Vols. 243-249, pp 6113-6117, doi:10.4028/www.scientific.net/AMR.243-249.6113. (C) 2011 Trans Tech Publications, Switzerland.

[3] Habiba Afrin (2017): A Review on Different Types Soil Stabilization Techniques. International Journal of Transportation Engineering and Technology. Vol. 3, No. 2, 2017, pp. 1924.doi:10.11648/j.ijtet.20170302.12.

[4] ASTM D 1883-94. Standard Test Method for CBR (California Bearing Ratio) of Laboratory- Compacted Soils. 1994v.

[5] AASHTO. (1999). Standard Method of Test for the California Bearing Ratio, T193-99, AASHTO, Washington, D.C.

[6] Chunmar, A.V. (1972), "Bearing Capacity Theory from Experimental Results," J. Geotech. Eng. Div., ASCE,Vol. 98, No. 12, pp. 1311-1324.

[7] AASHTO. 2012. LRFD Bridge Design Specifications, American Association of State Highway and Transportation Officials, Washington, DC.
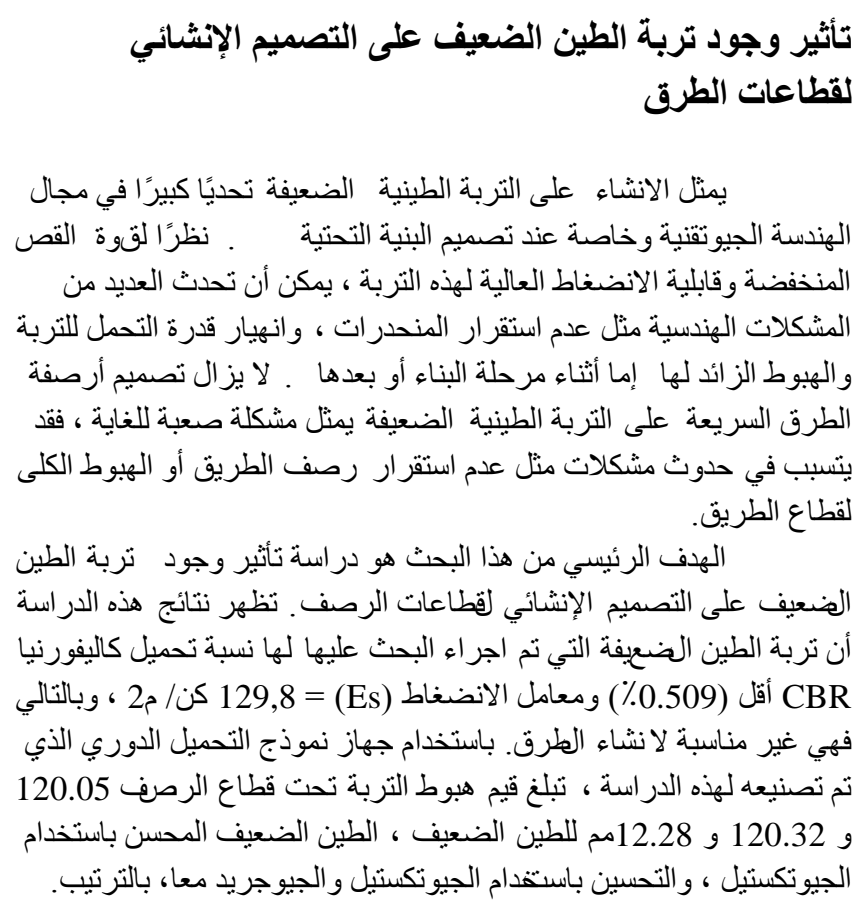